\title{
Usable water production from coal seam gas water with a combination of pore control fiber filtration and reverse osmosis
}

\author{
Choon Hwan Shin ${ }^{1^{+}}$, Jun Seok Bae $^{2}$ \\ ${ }^{1}$ Department of Energy \& Environmental Engineering, Dongseo University, Busan 47011, Republic of Korea \\ ${ }^{2}$ CSIRO Energy, 1 Technology Court, Pullenvale QLD 4069, Australia
}

\begin{abstract}
Coal seam gas (CSG) water, to be discharged, has been usually treated in reverse osmosis (RO) plants which require extensive and expensive pre-treatment. However, current low gas prices have been a great driver for relevant industries to seek for alternative cost-effective technologies in the aspect of its beneficial use and fit-for-purpose usable water production. In this paper, a combined system with a two-stage pore control fiber (PCF) filtration and a RO system was designed and tested for CSG water treatment. Also, a coagulation reactor was placed in front of the PCF to further enhance suspended solid removal. More than 99\% of SS were removed through the PCF filtration while organic, total nitrogen and total phosphorous were mostly removed by the RO system. Especially along with

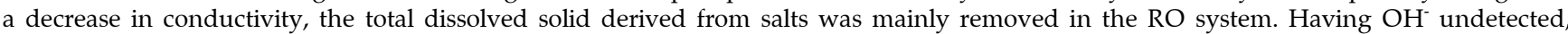
$\mathrm{HCO}_{3}{ }^{-}$was found to be a dominant compound and its removal efficiency was $97-98 \%$ after the RO treatment. And a Fe(III) type of Polytetsu, which was the first to be tested in this paper, was found to be a better option than a Al(III) type of Poly Aluminium Chloride due to its greater coagulation efficiency and applicability at a broader range of $\mathrm{pH}$ than the Al(III) type. In addition, there was no noticeable change in oxidation reduction potential, suggesting that an additional process is required to oxidize non-ionic organic carbons (detected as total organic carbon).
\end{abstract}

Keywords: Coagulation, Coal seam gas water, Filtration, Pore control fiber, Reverse osmosis, Usable water

\section{Introduction}

The ever-growing water demand has not been satisfied domestically and globally by water supply at the presence of abnormal climate changes such as uneven distribution of droughts and floods. Water is no longer a 'gift' from nature but is considered as a 'life-support resource'. As water is regarded as a renewable resource, compared to non-renewable resources such as coal and oil, various studies have been carried out to secure water resources over the recent decades [1-3]. New water resources can be created through three key words: water reuse, new technology development and water strategy education which reflect the importance of cyclic processes. Reused wastewater could be regarded as a new water resource, especially when it is used in regions where freshwater is scarce [4]. Especially, coal seam gas (CSG) water, which needs to be pumped out from coal seams for CSG production, had not been considered as a usable water resource in Australia until a new policy on CSG water management from Queensland State Government was recently released to encourage the beneficial used of CSG water [5]. CSG water, to be discharged, has been usually treated in reverse osmosis (RO) plants which require extensive and expensive pre-treatment. However, current low gas prices have been a great driver for relevant industries to seek for alternative cost-effective technologies in the aspect of its beneficial use and fit-for-purpose usable water production.

To design processes for usable water production, the sections of functional materials and application methods need to be viable to remove salts and total dissolved solid (TDS), hardness (mostly caused by the presence of $\mathrm{Ca}^{2+}$ and $\mathrm{Mg}^{2+}$ ), carbonates (i.e.
This is an Open Access article distributed under the terms of the Creative Commons Attribution Non-Commercial License (http://creativecommons.org/licenses/by-nc/3.0/) which permits unrestricted non-commercial use, distribution, and reproduction in any medium, provided the original work is properly cited.
Received October 29, 2017 Accepted January 27, 2018

${ }^{\dagger}$ Corresponding author

Email: 6116shin@dongseo.ac.kr

Tel: +82-51-320-1787 Fax: +82-51-320-1781

Copyright (C) 2018 Korean Society of Environmental Engineers 
Table 1. Operating Conditions of the PCF/RO System

\begin{tabular}{ccccccc}
\hline $\begin{array}{c}\text { Influent of PCF } \\
(\mathbf{L} / \mathbf{h})\end{array}$ & $\begin{array}{c}\text { Treated water } \\
\text { with } \mathbf{P C F}(\mathbf{L} / \mathbf{h})\end{array}$ & $\begin{array}{c}\text { Fiber volume } \\
\left(\mathbf{c m}^{\mathbf{3}}\right)\end{array}$ & $\begin{array}{c}\text { Treated water for unit } \\
\text { volume }\left(\mathbf{L} / \mathbf{m}^{\mathbf{3}} \cdot \mathbf{h}\right)\end{array}$ & $\begin{array}{c}\text { Influent of RO } \\
(\mathbf{L} / \mathbf{s e c})\end{array}$ & $\begin{array}{c}\text { Effluent } \\
(\mathbf{L} / \mathbf{h})\end{array}$ & $\begin{array}{c}\text { Ratio of effluent } \\
\text { over } \text { influent } \mathbf{( \% )}\end{array}$ \\
\hline 400 & 414 & 4,500 & 88.9 & 414 & 51 & 12.75 \\
\hline
\end{tabular}

$\mathrm{NaHCO}_{3}$ ), colour, petroleum compounds and organic matter (as total organic carbon (TOC)) [3]. In this study, a coagulation reactor, a pore control fiber (PCF) filtration system (which need relatively small footprints [6]) and a RO system (which is effective in removing ionic compounds [7, 8]) were combined to treat CSG water. Linking with our previous results [9] that analysed Australian government policy on the beneficial usage of CSG water [10], this paper presents a CSG water treatment option which is based on domestic technologies. A coagulation reactor was placed to further remove SS in front of the PCF. As Al ion in poly aluminium chloride (PAC) has recently been revealed to be one of substances that induce dementia, a Fe(III) type of Polytetsu as an alternative, which was developed by a domestic company, was selected and tested in this paper. Based on the test results, the potential of the combined system was evaluated for a usable water production system from CSG water. Also, this paper presents the treatment efficiencies in terms of water quality requirements for water supply purposes such as industrial, agricultural and domestic uses.

\section{Materials and Methods}

\subsection{Pilot Plant Construction and Operation}

As shown in Fig. 1, a small-scale pilot plant was designed and constructed to treat CSG water, consisting of a coagulation reactor, a two-stage PCF system and a RO system, having a timer function and a backwashing option. The PCF was selected as it requires less capital cost and footprint than membrane separation units. And asymmetric porous polyethylene membrane was used for the RO system. The design treatment capacities of the PCF and RO systems were 400 and $51 \mathrm{~L} / \mathrm{h}$, respectively. The volume ratio of effluent over influent was adjusted to be $12.75 \%$. The operating conditions are listed in Table 1. According to the average water quality in CSG water management

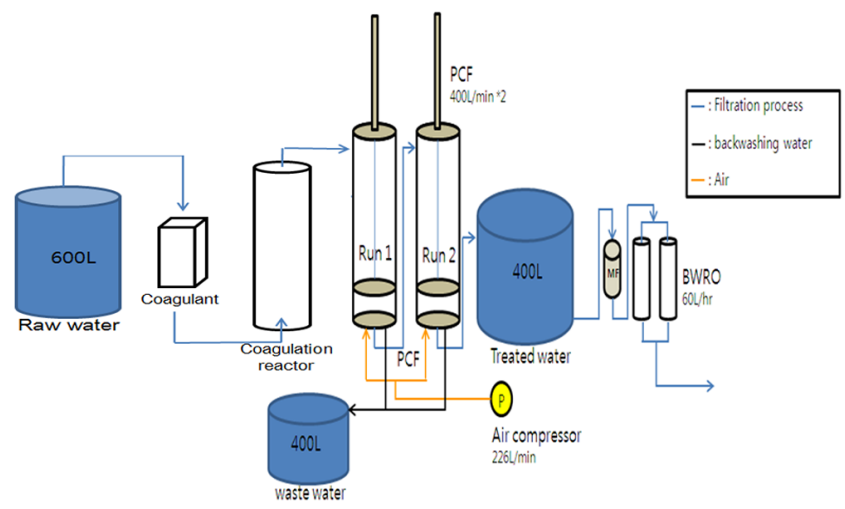

Fig. 1. Schematic diagram of a PCF/RO system.
Table 2. Average CSG Water Quality (DEHP, 2012)

\begin{tabular}{lcc}
\hline \multicolumn{1}{c}{ Water quality parameters } & Unit & Values \\
\hline $\mathrm{pH}$ & $\mathrm{mg} / \mathrm{L}$ & 9.07 \\
$\mathrm{TDS}$ & $\mathrm{mg} / \mathrm{L}$ & 4,450 \\
Sodium & $\mathrm{mg} / \mathrm{L}$ & 1,570 \\
Calcium & $\mathrm{mg} / \mathrm{L}$ & 6 \\
Magnesium & $\mathrm{mg} / \mathrm{L}$ & 2 \\
Potassium & $\mathrm{mg} / \mathrm{L}$ & 10 \\
Boron & $\mathrm{mg} / \mathrm{L}$ & 2.3 \\
Chloride & $\mathrm{mg} / \mathrm{L}$ & 1,140 \\
Sulphate & $\mathrm{mg} / \mathrm{L}$ & $<1$ \\
Bicarbonate & $\mathrm{mg} / \mathrm{L}$ & 1,710 \\
Total Organic Carbon (TOC) & $\mathrm{mg} / \mathrm{L}$ & 248 \\
Phenolic Compounds & $\mathrm{mg} / \mathrm{L}$ & $<1$ \\
Poly Aromatic Hydrocarbons & $\mathrm{mg} / \mathrm{L}$ & $<1$ \\
Total Petroleum Hydrocarbons & & $<60$ \\
C6 - C9 Fraction & $\mathrm{mg} / \mathrm{L}$ & $<1$ \\
C10 - C36 Fraction & $\mathrm{mg} / \mathrm{L}$ & $<5$ \\
BETX (sum) & $\mathrm{mg} / \mathrm{L}$ & $\mathrm{mg} / \mathrm{L}$ \\
Naphthalene & & $<20$ \\
\hline
\end{tabular}

Table 3. Simulated CSG Water Quality (concentration: mg/L)

\begin{tabular}{cccccc}
\hline COD & T-P & T-N & SS & Cl & NaHCO $_{3}$ \\
\hline \hline 420 & 1.0 & 24 & $1,000,2,000$ & 1,000 & 1,700 \\
\hline
\end{tabular}

policy [5] as listed in Table 2, a simulated CSG water was made and used in this paper, having water qualities listed in Table 3.

\subsection{Coagulants}

Due to its simplicity and effectiveness, coagulation-flocculation processes are regarded as one of the most important and widely used treatment process of raw water [11] and wastewater [12]. To improve the SS removal performance of the PCF system [11-13], along with a common type (Al(III) type of PAC), a newly developed Fe(III) type of Polytetsu by Cheong Woo ACE Co. [14] in South Korea was selected and their properties are listed in Tale 4. As $\mathrm{Al}$ ion in PAC is one of substances that induce dementia, a lot of effort has been devoted to seek for alternative coagulants. As part of our endeavours, a Fe(III) type of Polytetsu was selected to find out its applicability. Pre-determined conditions for the coagulation-flocculation process were used in this study. After confirming the coagulation areas, jar tests were carried out to obtain the coagulation efficiency with the concentration ranges of $10,20,30,40$ and $50 \mathrm{ppm}$ at $\mathrm{pH}$ of 5,7 and 9 for PAC and 4, 7 and 10 for Polytetsu [15]. 


\section{Results and Discussion}

\subsection{Analysis of CSG Water}

According to the average CSG water qualities in Table 2 [5, 16], the sum of sodium, calcium, magnesium, potassium, boron, chloride and TOC concentrations is about $4,688 \mathrm{mg} / \mathrm{L}$. As the TDS concentration is $4,450 \mathrm{mg} / \mathrm{L}$, the difference $(238 \mathrm{mg} / \mathrm{L})$ from the sum is a portion that was not detected as TDS. If TOC (248 $\mathrm{mg} / \mathrm{L}$ ) is excluded, the sum is similar to the TDS concentration. This suggests that the TOC in Table 2 may not be ionic organic carbons. This factor was used for the system design.

\subsection{Prediction of Coagulant Molecular Weights}

The molecular formula of the selected PAC is $\left[\mathrm{Al}_{2}(\mathrm{OH})_{\mathrm{n}} \mathrm{Cl}_{6-\mathrm{n}}\right]_{\mathrm{m}}$ $(1 \leq \mathrm{n} \leq 5, \mathrm{~m} \leq 10$, alkalinity: $\mathrm{n} / 6 \times 100)$ with $17 \%$ of $\mathrm{Al}_{2} \mathrm{O}_{3}$. As the selected PAC has more than $35 \%$ of alkalinity, $n$ is expected to be more than 2. However, considering the fact that the $\mathrm{pH}$ region in the coagulation gets narrower with higher alkalinity, $n$ would be 2 or 3 . As the PAC is an inorganic coagulant, the degree $(\mathrm{m})$ of polymerization to increase the molecular weight would be maximum 10. Therefore the molecular weight distribution can be estimated between 2,990 and 3,150 (average 3,000). Also, $\left[\mathrm{Fe}_{2}(\mathrm{OH})_{\mathrm{n}}\left(\mathrm{SO}_{4}\right)_{3-\mathrm{n}}\right]_{\mathrm{m}}(0 \leq \mathrm{n} \leq 2, \mathrm{~m}=\mathrm{f}(\mathrm{n}))$ as a Polytetsu was used. As it has $3 \mathrm{D}$ configuration with some of $\mathrm{SO}_{4}^{-2}$ being substituted with $\mathrm{OH}^{-}$and the alkalinity is high, $n$ is estimated to be 2 with $m$ being 10 (the same as PAC), resulting in the molecular weight of $2,416[17,18]$.

\subsection{Linear Regression between Concentration and Turbidity of Coagulants}

As the relationship between feed concentration and turbidity of the selected coagulants is an important aspect of coagulant characteristics $[19,20]$, it was obtained with respect to $\mathrm{pH}$ and

Table 4. Properties of Coagulants (PAC and Polytetsu)

\begin{tabular}{|c|c|c|}
\hline Coagulant & Properties & Specification \\
\hline \multirow[t]{7}{*}{ PAC } & Specific gravity & $>1.19$ \\
\hline & Aluminium oxide & Туре 1: 10.0-12.0\% \\
\hline & & Type 2: 12.0-15.0\% \\
\hline & & Type 3: 15.0-18.0\% \\
\hline & Alkalinity & $>35 \%$ \\
\hline & $\mathrm{pH}$ & $3.5-5.5$ \\
\hline & $\mathrm{SO}_{4}$ & $<3.5 \%$ \\
\hline \multirow[t]{8}{*}{ Polytetsu } & Appearance & Reddish brown liquid \\
\hline & Specific gravity $\left(20^{\circ} \mathrm{C}\right)$ & $1.45-1.49$ \\
\hline & Viscosity $\left(20^{\circ} \mathrm{C}\right)$ & $10-30 \mathrm{cps}$ \\
\hline & $\mathrm{pH}(1 \mathrm{w} / \mathrm{v} \%)$ & $>2$ \\
\hline & Total Fe & $>11 \%$ \\
\hline & $\mathrm{Fe}(\mathrm{II})$ & $<0.07 \%$ \\
\hline & $\mathrm{SO}_{4}^{2-}$ & $24-29 \%$ \\
\hline & $\mathrm{Cl}^{-}$ & $<0.05 \%$ \\
\hline
\end{tabular}

Table 5. Linear Regression between Concentration and Turbidity of Coagulants Used with Respect to $\mathrm{pH}$

\begin{tabular}{cccc}
\hline Coagulant & $\mathbf{p H}$ & Slope & $\mathbf{R}^{2}$ \\
\hline \hline PAC & 4 & 68.84 & 0.940 \\
& 7 & 70.47 & 0.918 \\
Polytetsu & 9 & 67.00 & 0.930 \\
& 5 & 108.84 & 0.958 \\
& 7 & 117.82 & 0.950 \\
& 10 & 107.15 & 0.970 \\
\hline
\end{tabular}

the linear regression results are listed in Table 5. The PAC was found to have slopes of $68.84,70.47$ and 67.00 with $\mathrm{R}^{2}$ of 0.940 , 0.918 and 0.930 at $\mathrm{pH}$ of 4,7 and 9, respectively, indicating that the impact of $\mathrm{pH}$ is insignificant. This could be due to the fact that $\mathrm{pH}$ affects the concentrations of ionic species in aqueous solution. Similarly, a consistent trend was observed for the Polytetsu having slopes of 108.84, 117.82 and 107.15 with $\mathrm{R}^{2}$ of $0.958,0.950$ and 0.970 at $\mathrm{pH}$ of 5,7 and 10 , respectively. Also, the turbidity of Polytetsu was more rapidly increased as the feed concentration rises, compared to that of PAC.

\subsection{Coagulation Areas of PAC}

Possible types of $\mathrm{Al}^{3+}$ complexes in an aqueous solution were considered as below and their concentrations are plotted with respect to $\mathrm{pH}$ in Fig. 2 .

$$
\begin{gathered}
\mathrm{Al}^{3+}+\mathrm{H}_{2} \mathrm{O} \leftrightarrow \mathrm{Al}(\mathrm{OH})^{2+}+\mathrm{H}^{+} ; \log \mathrm{K}_{1}=-5 \\
\mathrm{Al}(\mathrm{OH})_{3(\mathrm{~S})} \leftrightarrow \mathrm{Al}^{+3}+3 \mathrm{OH}^{-} ; \log \mathrm{K}_{\mathrm{SO}}=-33 \\
\mathrm{Al}(\mathrm{OH})_{3(\mathrm{~S})}+\mathrm{OH}^{-} \leftrightarrow \mathrm{Al}(\mathrm{OH})_{4}^{-} ; \log \mathrm{K}_{\mathrm{S} 4}=1.3 \\
2 \mathrm{Al}^{3+}+2 \mathrm{H}_{2} \mathrm{O} \leftrightarrow \mathrm{Al}_{2}(\mathrm{OH})_{2}{ }^{4+}+2 \mathrm{H}^{+} ; \operatorname{logK}=-6.3 \\
\mathrm{H}^{+}+\mathrm{OH}^{-} \leftrightarrow \mathrm{H}_{2} \mathrm{O} ; \operatorname{logKw}=-14
\end{gathered}
$$

As can be seen in Fig. 2, all coagulant concentrations are inside the coagulation area at $\mathrm{pH}$ between 5 and 7 whereas they are located at the outer area at $\mathrm{pH}$ 9. In the case of high alkalinity, the high concentration of $\mathrm{OH}^{-}$would yield aqueous dispersion of ionic species, leaving the coagulants out of the

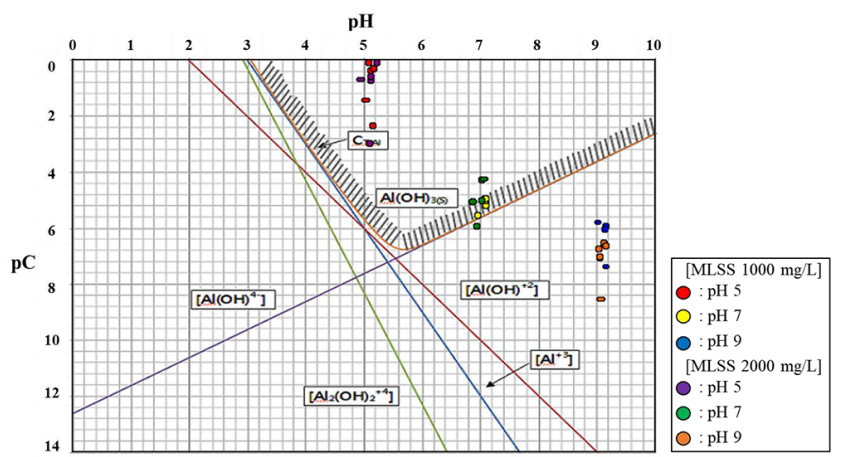

Fig. 2. Coagulation area of poly aluminium chloride (PAC). 
coagulation area. The coagulation efficiency was found to be optimum at $\mathrm{pH}$ 7. Therefore, if PAC is used for the pilot plant, then $\mathrm{pH}$ needs to be close to 7 [21]. This is one of design criteria.

\subsection{Coagulation areas of Polytetsu}

Similar to the case of PAC, possible types of $\mathrm{Fe}^{3+}$ complexes in raw water with SS of 1,000 and 2,000 ppm were selected as below and their coagulation area is platted at broader $\mathrm{pH}$ (4, 7 and 10) than for PAC in Fig. 3.

$$
\begin{gathered}
\mathrm{Fe}(\mathrm{OH})_{3(\mathrm{~S})} \leftrightarrow \mathrm{Fe}(\mathrm{OH})_{2}^{+}+2 \mathrm{OH}^{-} ; \log \mathrm{S}_{\mathrm{S} 1}=-26.16 \\
\mathrm{Fe}(\mathrm{OH})_{3(\mathrm{~S})} \leftrightarrow \mathrm{Fe}(\mathrm{OH})_{2}^{+}+\mathrm{OH}^{-} ; \log \mathrm{K}_{\mathrm{S} 2}=-16.74 \\
\mathrm{Fe}(\mathrm{OH})_{3(\mathrm{~S})}+\mathrm{OH}^{-} \leftrightarrow \mathrm{Fe}(\mathrm{OH})_{4}^{-} ; \log \mathrm{K}_{\mathrm{S} 4}=-5 \\
2 \mathrm{Fe}(\mathrm{OH})_{3(\mathrm{~S})} \leftrightarrow \mathrm{Fe}_{2}(\mathrm{OH})_{2}^{4+}+4 \mathrm{OH}^{-} ; \operatorname{logK}=-50.8 \\
2 \mathrm{Fe}^{3+}+2 \mathrm{H}_{2} \mathrm{O} \leftrightarrow \mathrm{Fe}_{2}(\mathrm{OH})_{2}{ }^{4+}+2 \mathrm{H}^{+} ; \operatorname{logK}=-2.85
\end{gathered}
$$

The Polytetsu seems to be out of the coagulation area at $\mathrm{pH} 4$. However, as $\mathrm{Fe}(\mathrm{OH})_{2}{ }^{+}, \mathrm{Fe}(\mathrm{OH})^{2+}$ and $\mathrm{Fe}(\mathrm{OH})_{3(\mathrm{~S})}$ are present at similar concentrations, a similar coagulation efficiency was observed, regardless of the $\mathrm{pH}$ range used in this study [22]. This indicates that coagulation still takes place even if a certain amount of ionic complexes is present. Therefore, unlike the PAC, it is confirmed that the Polytetsu is always in the coagulation area at the $\mathrm{pH}$ range studied. Thus, although the Polytetsu with Fe(III) ion has slightly lower estimated molecular weight than the PAC, the former can be applied at broader $\mathrm{pH}$ range than

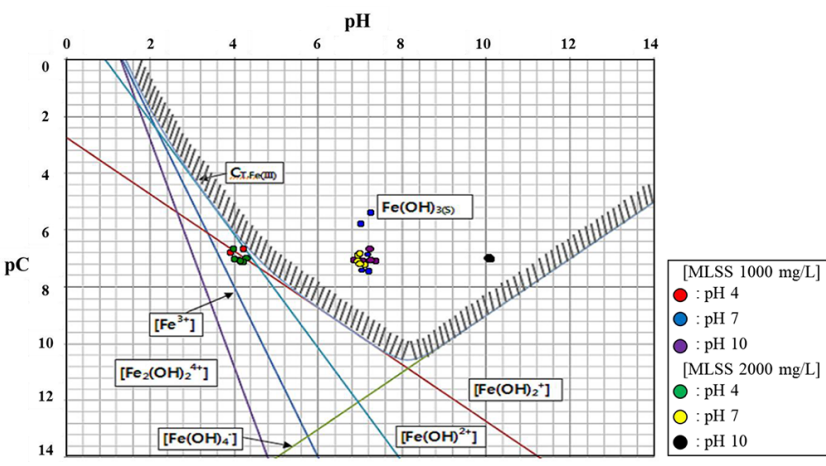

Fig. 3. Coagulation area of Polytetsu.

the latter. The supernatant after coagulation was about $10^{-7} \mathrm{M}$, indicating that the Polytetsu is better than the PAC in terms of optimum coagulation concentrations. Therefore, it can be said that a coagulation system with a Fe(III) type of Polytetsu in front of the PCF system is an effective option [6] for the operation of the pilot plant constructed in this study.

\subsection{Preliminary Operation of Pilot Plant}

The PCF/RO system was operated using a Fe(III) type of Polytetsu coagulants and the preliminary results are listed in Table 6 . As the Polytetsu coagulant in front of the PCF/RO system made the floc size enlarged, more than $99 \%$ of SS were removed through

\begin{tabular}{|c|c|c|c|c|c|c|c|c|c|c|}
\hline & $\begin{array}{l}\mathrm{COD}_{\mathrm{Mn}} \\
(\mathrm{mg} / \mathrm{L})\end{array}$ & $\begin{array}{l}\mathrm{COD}_{\mathrm{Cr}} \\
(\mathrm{mg} / \mathrm{L})\end{array}$ & $\begin{array}{c}\mathrm{T}-\mathrm{N} \\
(\mathrm{mg} / \mathrm{L})\end{array}$ & $\begin{array}{c}\mathrm{T}-\mathrm{P} \\
(\mathrm{mg} / \mathrm{L})\end{array}$ & $\begin{array}{c}\text { conductivity } \\
(\mu \mathrm{S} / \mathrm{cm})\end{array}$ & $\begin{array}{l}\text { ORP } \\
(\mathrm{mV})\end{array}$ & $\begin{array}{c}\mathrm{SS} \\
(\mathrm{mg} / \mathrm{L})\end{array}$ & $\begin{array}{c}\text { TDS } \\
(\mathrm{mg} / \mathrm{L})\end{array}$ & $\begin{array}{c}\text { DO } \\
(\mathrm{mg} / \mathrm{L})\end{array}$ & $\mathrm{pH}$ \\
\hline Blank & & & & & 182.8 & & & 123.5 & & 7.37 \\
\hline Raw water & 145.4 & 298.4 & 20.66 & 0.98 & 1,505 & 155 & 438 & 977 & 6.3 & 8.26 \\
\hline PCF1 (20 min) & 100.7 & 189.9 & 17.94 & 0.92 & 1,241 & 149 & 6 & 1,570 & 6.6 & 8.44 \\
\hline PCF2 (40 min) & 98.9 & 178.5 & 15.45 & 0.78 & 1,011 & 181 & 8 & 1,533 & 6.8 & 8.42 \\
\hline PCF3 (60 min) & 101.2 & 182.4 & 17.36 & 0.83 & 1,055 & 161 & 4 & 1,500 & 7.3 & 8.41 \\
\hline RO1 (20 min) & L.R & L.R & L.R & L.R & 33.5 & 132 & 0 & 26.6 & 3.6 & 6.29 \\
\hline RO2 (40 min) & L.R & L.R & L.R & L.R & 40.6 & 164 & 0 & 75.2 & 4.8 & 6.83 \\
\hline RO3 (60 min) & L.R & L.R & L.R & L.R & 70.5 & 136 & 0 & 70.3 & 5.0 & 6.92 \\
\hline
\end{tabular}
the PCF process. After 20 min of operation, the SS removal efficiency was stabilized, suggesting that 20 min would be an

\begin{tabular}{|c|c|c|c|c|c|c|}
\hline & T-alkalinity & M-alkalinity & P-alkalinity & $\mathrm{OH}^{-}$ & $\mathrm{CO}_{3}{ }^{2-}$ & $\mathrm{HCO}_{3}^{-}$ \\
\hline Raw water & 1,126 & 1,126 & 84 & 0 & 168 & 958 \\
\hline PCF1 (20 min) & 1,088 & 1,088 & 63 & 0 & 126 & 962 \\
\hline PCF2 (40 min) & 1,098 & 1,098 & 63 & 0 & 126 & 972 \\
\hline PCF3 (60 min) & 1,090 & 1,090 & 42 & 0 & 84 & 1,006 \\
\hline RO1 (20 min) & 19 & 19 & 0 & 0 & 0 & 19 \\
\hline RO2 (40 min) & 27 & 27 & 0 & 0 & 0 & 27 \\
\hline RO3 (60 min) & 17 & 17 & 0 & 0 & 0 & 17 \\
\hline
\end{tabular}
optimum condition, considering the energy consumption.

Table 6. Operating Results of the PCF/RO System.

Table 7. Alkalinity Change in the Course of the PCF/RO System Operation 
However, the removal efficiencies of organic, total nitrogen (T-N) and total phosphorous (T-P) were found to be low (30.4-32.0, 13.0-25.0 and 6.0-20.4\%, respectively) with the PCF process while most of them were removed to undetectable levels with the RO system. In particular, along with a decrease in conductivity, as the TDS derived from salts was removed in the RO system, it is necessary to have a RO system to meet the TDS discharge level $(<500 \mathrm{mg} / \mathrm{L})$ for drinking water [5]. In addition, extensive pre-treatment processes such as the PCF in this study are required to reduce $\mathrm{RO}$ membrane fouling. As listed in Table $7, \mathrm{OH}^{-}, \mathrm{HCO}_{3}{ }^{-}$and $\mathrm{CO}_{3}{ }^{2-}$ were measured for $\mathrm{M}$ and $\mathrm{P}$ alkalinities [23-25]. Having $\mathrm{OH}^{-}$undetected, $\mathrm{HCO}_{3}^{-}$was found to be dominant, being removed up to $97-98 \%$ with the RO process. Especially, there was no noticeable change in ORP, which can be used to predict oxidation-reduction reaction at the early stage operation. This suggests that an additional process is required to oxidize non-ionic organic carbons (detected as TOC). Therefore, for the operational demonstration of the pilot plant using these results, the effects of carbonate on organic matter oxidation, CSG water storage and transport will be investigated in near future.

\section{Conclusions}

In this paper, a combined system with a coagulation reactor, a two-stage PCF filtration system and a RO system was constructed and tested for CSG water treatment. To improve the PCF filtration efficiency, a Fe(III) type of Polytetsu was found to be a better option than a $\mathrm{Al}(\mathrm{III})$ type of PAC due to its greater coagulation efficiency and applicability at a broader range of $\mathrm{pH}$ than the latter. The PCF filtration process removed 99\% of SS while the RO system removed most of organic, T-N and T-P. In particular, along with a decrease in conductivity, the TDS derived from salts was removed in the RO process. To meet the TDS discharge standard $(<500 \mathrm{mg} / \mathrm{L})$ for drinking water, it is found that a RO process is still required.

As the preliminary operation results showed no noticeable change in ORP, an additional process is required to oxidize non-ionic organic carbons (detected as TOC). From the measurement of $\mathrm{OH}^{-}, \mathrm{HCO}_{3}{ }^{-}$and $\mathrm{CO}_{3}{ }^{2-}$ in terms of $\mathrm{M}$ and $\mathrm{P}$ alkalinities, $\mathrm{HCO}_{3}{ }^{-}$was a dominant compound, being removed 97-98\% with the $\mathrm{RO}$ process. $\mathrm{OH}^{-}$was not detected. Thus, for the operational demonstration of the pilot plant using these results, the effects of carbonate on organic matter oxidation, CSG water storage and transportation will be investigated in near future. Also, a range of fit-for-purpose system designs for beneficial uses of CSG water will be presented in the next study.

\section{Acknowledgments}

This study was conducted with a part of final report submitted to Busan Green Environment Center (BGEC) and was supported by Dongseo University, "Dongseo Frontier Project" Research Fund of 2016.

\section{References}

1. Amirtharajah A, Mills KM. Rapid-mix design for mechanisms of alum coagulation. Am. Water Works Assoc. 1982;74:210-216.

2. Chris M. Approach to understanding and managing impacts of co-produced water. In: 5th Annual CSG Associated Water Conference; 2013.

3. Dong H, Gao B, Yue Q, Sun S, Wang Y, Li Q. Floc properties and membrane fouling of different monomer and polymer Fe coagulants in coagulation-ultrafiltration process: The role of Fe(III) species. Chem. Eng. J. 2014;258:442-449.

4. Wu TY, Mohammad AW, Lim SL, Lim PN, Hay JXW. Recent advances in the reuse of wastewaters for promoting sustainable development. In: Sharma SK, Sanghi R, eds. Wastewater reuse and management. Netherlands: Springer; 2013. p. 47-103.

5. Energy Resources, Department of Environment and Heritage Protection Government, the State of Queensland, 2012. Coal Seam Gas Water Management Policy 2012.

6. Energy O. CSG water production forecasts. Water treatment (Process option, Water retention pond and evaporation); 2013.

7. Gregory J, Nelson DW. A new optical method for flocculation monitoring. In: Gregory J, ed. Solid-liquid separation. Chichester: Ellis Horwood; 1984. p. 172-182.

8. Heiderscheidt E, Saukkoriipi J, Ronkanen A, Kløve B. Optimisation of chemical purification conditions for direct application of solid metal salt coagulants: Treatment of peatland-derived diffuse runoff. J. Environ. Sci. 2013;25:659-669.

9. Shin C. Assessment and analysis of coal seam gas water management study for water resource production 2 . Prediction of treatment technology and design of co-treatment system. J. Environ. Sci. Int. 2015;24:1629-1637.

10. AUS Department of Environment and Heritage Protection, Queensland. Water quality criteria for coal seam gas water. 2013.

11. Teh CY, Wu TY. The potential use of natural coagulants and flocculants in the treatment of urban waters. Chem. Eng. Transactions 2014;39:1603-1608.

12. Teh CY, Budiman PM, Shak KPY, Wu TY. Recent advancement of coagulation-flocculation and its application in wastewater treatment. Ind. Eng. Chem. Res. 2016;55:4363-4389.

13. Liu X, Li X, Yang Q, et al. Landfill leachate pretreatment by coagulation-flocculation process using iron-based coagulants: Optimization by response surface methodology. Chem. Eng. J. 2012;200:39-51.

14. Chungwoo Ace Co. Technical report. Development of Fe(III) type of polytetsu and removal efficiency of suspended solid. 2015.

15. Matsui Y, Tambo N. Online floc size evaluation by photometric dispersion analyser. Water Supply 1991;9:71-78.

16. Petri M, Jiang J, Maier M. Screening analysis of volatile organic contaminants in commercial inorganic coagulants used for drinking water treatment. J. Environ. Manage. 2009;91:142-148.

17. Randol C. Managing the impacts of CSG water extraction in the Surat Basin. In: 5th Annual CSG Associated Water Conference; 2013. 
18. Shin C. Assessment and analysis of coal seam gas water management study for water resource production-1. Water production. J. Environ. Sci. Int. 2014;23:1395-1407.

19. Shin C, Bae J. A stability study of an advanced co-treatment system for dye wastewater reuse. J. Ind. Eng. Chem. 2012;18;775-779.

20. Shin C, Bae J, Rudolph V. Co-treatment systems combined with unit processes for dye wastewater recycling. J. Ind. Eng. Chem. 2014;20:710-716.

21. Snoeyink VL, Jenkins D. Water chemistry. Wiley; 1980. 22. SSENG Co. Technical report. Development of 2-stage fiber filtration process for the reuse of sewage. 2012.

23. Nan Z, Huang Y, Zhu R, Xue-Liang Z. Fast detection of carbonate and bicarbonate in groundwater and lake water by coupled ion selective electrode. Chinese J. Anal. Chem. 2016;44:355-360.

24. Stumm W, Morgan JJ. Aquatic chemistry: Chemical equilibria and rates in natural waters. John Wiley \& Sons; 2012.

25. Umar M, Roddick F, Fan L. Comparison of coagulation efficiency of aluminium and ferric-based coagulants as pre-treatment for UVC/ $\mathrm{H}_{2} \mathrm{O}_{2}$ treatment of wastewater RO concentrate. Chem. Eng. J. 2016;284:841-849. 